\title{
MEMBANGUN IDENTITAS NASIONAL MELALUI TEKS: REVIEW SINGKAT TERHADAP TEKS SASTRA DALAM BUKU TEKS BAHASA INDONESIA
}

\author{
Ruruh Sarasati \\ UIN Walisongo Semarang \\ email: rsaraswati@gmail.com
}

\begin{abstract}
(Title: Building National Identity through Text: A Brief Review of Literary Texts in Indonesian Language Textbooks). Indonesia is a multi-ethnic, multi-culture, and multi-religion country. Nowadays, Indonesia is facing some serious problems related to nationality. Therefore, cultivating students' national identity is important because students are the generation who will run this country. Students must be aware of their identity in respect of country, ethnicity, and culture. One of the ways is through literary text. This article reviews literary texts that are found in student textbook and how they can construct and cultivate national identity. There are four kinds of national identity in poetry written in the textbook: religion, language, ethnic, and local custom.
\end{abstract}

Keywords: national identity, literary text, text book, students

\section{PENDAHULUAN}

Identitas tidak dapat dilepaskan dari kehidupan karena setiap saat manusia dihadapkan pada pertanyaan "siapa kita", oleh karenanya, bahasan mengenai identitas menjadi fokus para cendekiawan ilmu sosial, linguis, dan guru bahasa. Kajian mengenai identitas dianggap penting karena melalui kajian tersebut dapat diperoleh gambaran mengenai bagaimana individu atau kelompok mempraktikkan dirinya dalam kehidupan politik, sosial, maupun dalam kehidupan bermasyarakat, berbangsa dan bernegara. Salah satu yang mejadi fokus adalah identitas pada siswa. Anak-anak usia SMP mulai mencari dan membentuk identitasnya.

Pembentukan identitas tersebut tidak hanya ditentukan oleh satu faktor saja, melainkan oleh berbagai macam faktor. Salah satu faktor yang berpengaruh terhadap pembentukan identitas anak adalah identitas yang tersirat di dalam karya sastra.

Setiap karya sastra memiliki identitas tersirat, baik itu identitas diri penulis, identitas sosial, identitas budaya, maupun identitas nasional. Identitas yang terdapat dalam karya sastra dapat berpengaruh terhadap identitas pembacanya karena pembaca sedang berada dalam tahapan pembentukan identitas sehingga pembaca akan cenderung mengadopsi identitas-identitas yang biasa bersinggungan dengannya.

Identitas nasional secara harfiah terdiri atas kata identitas dan nasional. Identitas (identity) berasal dari bahasa Latin yaitu idem yang menandai adanya kesamaan individual kesamaan pada diri seseorang selama kurun waktu tertentu. "Kesamaan" pada diri individu tersebut membedakan individu yang satu dengan individu yang lain, sebuah fakta bahwa orang tersebut adalah dirinya sendiri, dan bukan orang lain. Identitas merupakan suatu hal yang berkesinambungan sepanjang kehidupan seseorang dan bersifat tidak terbatas (Barker, 2004:94; Edwards, 2009: 19). Meskipun demikian, terdapat relasi yang pasti dan penting antara identitas inividual seseorang dan kelompoknya. Pada level personal, seorang individu akan menganggap nilai-nilai sebuah integritas yang dimiliki oleh integritas pribadinya, namun pada level kelompok, identitas tersebut lahir dari kelangsungan relasi yang timbul berdasarkan sejarah dan berlangsung terus menerus melalui tradisi dalam sebuah kelompok.

Sementara itu, kata national berasal dari kata nation yang dapat diartikan sebagai sekelompok manusia yang tinggal di sebuah 
wilayah dan memiliki sejarah historis tentang wilayahnya, memiliki sejarah yang ditulis, berbagi kebudayaan yang sama, memiliki nenek moyangyang sama, memiliki simbol, tradisi, dan adat istiadat, serta memiliki kesadaran sebagai bangsa dan memiliki status politik (Barret \& Davis, 2008: 73).

Identitas nasional merupakan konstruk yang diturunkan dari konstruk nasionalitas, yakni rasa keterikatan seseorang terhadap sebuah negara. Identitas nasional merupakan sebuah konsep kompleks yang terdiri atas berbagai komponen berikut (Barret, 2005: 188), yaitu a) pengakuan subjektif sebagai bagian dari bangsa tertentu, b) merasa identitas nasional menjadi bagian dari identitas individu, c) memiliki emosi (baik positif atau negatif) terhadap negara, d) stereotipe mengenai tipikal karakteristik dan perilaku seseorang sebagai bagian dari kelompok, e) pengalaman subyektif namun mirip antara anggota kelompok yang satu dengan yang lain, f). Opini subjektif didasarkan pada tujuan yang dimiliki dan permasalahan yang dihadapi negara, h) adanya pengetahuan dan keinginan untuk menyatu dengan budaya nasional, nilai, dan tata perilaku yang berlaku pada sebuah bangsa.

Identitas nasional dapat ditemukan dalam kehidupan sehari-hari sebuah kelompok. Identitas tersebut tersermin dalam interaksi sosial, kebiasaan, rutinitas, dan praktikpraktik pengetahuan (Edensor, 2002: 16). Oleh karenanya, identitas nasional tidak dapat dipandang sebagai entitas yang serta merta sebagai hal yang sudah dimiliki, melainkan hal yang terbentuk seiring perjalanan. Identitas nasional merupakan sebuah konstruk sosial, meskipun demikian, identitas nasional dapat berubah seiring dengan perubahan psikososial yang berlaku. Identitas nasional biasanya hadir dalam derajat yang berbeda-beda, namun biasanya identitas nasional tersebut akan muncul saat berlangsungnya kegiatan olahraga berskala internasionalatau ketika ada ancaman terhadap sebuah bangsa yang berasal dari luar. Contoh tersebut misalnya saat pertandingan sepakbola dan pada saat salah satu budaya Indonesia diklaim oleh bangsa lain.

Identitas nasional adalah batasanbatasan yang diterapkan oleh sekelompok inividu dan mengidentifikasi perbedaan antara kelompok tersebut dengan kelompok yang lain. Dengan demikian, identtas nasional melekat pada kelompok yang besar danmembedakan dengan kelompok lainnya yang diikat oleh kesamaan budaya, agama, dan bahasa, maupun cita-cita dan tujuan. Identitas nasional merupakan jati diri sebuah bangsa dan membedakannya dengan bangsa yang lain. Di Indonesia, identitas nasional merujuk pada kumpulan nilai dan budaya yang terbentuk dari berbagai suku bangsa yang terhimpun alam kebudayaan nasional.

Unsur identitas nasional di Indonesia merujuk pada bangsa yang majemuk yang merupakan gabunganunsurpembentuk meliputi identitas fundamental, identitas instrumental, dan identitas alamiah (Herdiawanto dan Hamadayama, 2010). Identitas fundamental meliputi Pancasila yang merupakan falsafah hidup bangsa, dasar negara, dan ideologi negara. Sementara itu, identitas instrumental meliputi UUD 1945 dan tata perundangannya, bahasa Indonesia, bendera negara, lambang negara, dan lagu kebangsaan Indonesia raya. Sementara itu, identitas alamiah meliputi identitas negara kepulauan (archipelago) dan pluralisme yang terwujud dalam agama, budaya, suku, bahasa, serta kepercayaan.

Suku bangsa merupakan golongan yang bersifat khusus dan sejak lahir dan terbentuk secara tuun temurun. Identitas dan atribut kesukuan dari suatu kelompok masyarakat akan diwariskan kepaa generasi berikutnya. Dengan demikian, identitas dan atribut suku bangsa langsung melekat pada diri seseorang sesuai dengan suku bangsa kedua orang tuanya. Suku bangsa di Indonesia ditentukan mengikuti garis paternalistik (ayah/laki-laki), misalnya Suku Jawa dan Suku Batak. Selian itu, suku bangsa di Indonesia mengikuti garis maternalistik (ibu/perempuan) misalnya suku Minangkabau (BPS, 2011: 5).

Jumlah suku bangsa yang ada di Indonesia secara keseluruhan mencapai lebihdari 1.300 suku bangsa. Selain suku bangsa di Indonesia beragam jenisnya, jumlah atau populasi setiap suku bangsa juga bervariasi. Suku bangsa yang terbesar populasinya adalah suku Jawa (40\%) dari populasi pendduk 
Indonesia. Secara berturut-turut, suku bangsa terbesar di Indonesia adalah suku Jawa, Sunda, Batak, dansuku asal Sulawesi yang masingmasing jumlahnya lebih dari 7 juta jiwa. Sementara itu, populasi Suku Bantik, Wamesa, Uno, Lepo Tau, dan Halmahera masing-masing memiliki jumlah populasi kurang dari 10 ribu jiwa.

Selain dikenal sebagai negara yang memiliki beragam suku bangsa, Indonesia juga dikenal sebagai negara yang masyarakatnya dikenal agamis. Agama yang diakui secara resmi di Indonesia meliputi agama Islam, Kristen, Katolik, Hindu, Budha, Khonghucu, dan lainnya. Identitas nasional Indonesia tidak dapa dilepaskan dari kemajmukan agama yang dianut warganya. Kehidupan beragama di masyarakat bersifat heterogen dengan berbagai latar belakang agama. Toleransi masyarakat Indonesia juga terbangun dan dapat dilihat dari kegiatan gotong royong yang dilakukan bersama-sama oleh anggota masyarakat. Suasana tersut didukung oleh pemerintah yang menjamin kebebasan setiap warga negara untuk memeluk agama dan kepercayaan sesuai dengan keyakinannya masing-masing. Agama yang paling banyak dianut di Indonesia secara berturut-turut adalah agama Islam, Kristen, Katolik, Hindu, Budha, Khonghucu dan lainnya (BPS, 2011: 11).

Bahasa merupakan bahasa yang tercermin dalam komunikasi sehari-hari di rumah antarsesama anggota keluarga. Bahasa sehari-hari yang dipakai oleh seseorang tidak selalu didasarkan pada keturunan, melainkan terbentuk karena proses interaksi sosial. Dalam Sensus Penduduk 2010, bahasa daerah juga beragam. Secara umum, mayoritas penduduk Indonesia masih menggunakan bahasa daerah untuk berkomunikasi sehari-hari dalam rumah tangga (BPS, 2011: 11). Meskipun demikian, presentase penduduk yang menggunakan bahasa Indonesia sebagai bahasa sehari-hari di rumah tangga semakin meningkat dibandingkan dengan tahun-tahun sebelumnya.

Penelitian ini diharap mampu melengkapi studi mengenai identitas pada karya sastra yang telah ada sebelumnya. Penelitian tersebut antara lain penelitian mengenai identitas keindonesiaan novel karya anak Indonesia (Suyatno, 2014), identitas kebangsaan yang ada pada puisi (Darmawati, 2017) dan identitas nasional dalam buku teks pelajaran sejarah SMA (Sumaludin, 2018). Perbedaan penelitian ini dan penelitian sebelumnya terletak pada fokus kajian. Identitas keindonesiaan yang diteliti oleh Suyatno (2014) merupakan identitas keindonesiaan yang meliputi penggunaan simbol-simbol negara berupa bendera, lagu kebangsaan, dan lain sebagainya dalam novel karya anak, sementara identitas nasional dalam kajian ini dibatasi pada munculnya suku, agama, bahasa, dan adat istiadat dalam puisi yang ada di buku teks. Kajian ini juga berbeda dengan kajian yang ditulis oleh Darmawati (2017). Pada kajian tersebut, Darmawati mengkaji identitas kebangsaan melalui puisi dengan lebih menekankan pada nilai-nilai luhur bangsa Indonesia melalui tema dan amanat yang ada dalam puisi, sementara pada penelitian ini lebih menekankan pada identitas nasional.

Penelitian mengenai identitas personal, sosial, dan budaya yang ada selama ini lebih banyak menyoroti identitas-identitas dalam karya sastra. Literatur mengenai identitas nasional yang terdapat dalam teks sastra yang digunakan dalam buku teks di sekolah masih sangat terbatas. Padahal, karya astra yang ada di buku teks merupakan karya sastra yang "minimal" pasti dibaca oleh siswa sehingga karya sastra tersebut memiliki implikasi terhadap pembacanya.

\section{METODE}

Penelitian ini merupakan penelitian kualitatif dan termasuk jenis penelitian pustaka. Analisis yang digunakan adalah analisis isi atau analisis konten. Langkahlangkahnya meliputi (1) penginterpretasian sumber data (2) pengelompokan sumber data (3) pengelompokan data, (4) pengaitan dengan aspek lain (4) penyimpulan. Penelitian ini menggunakan 15 puisi yang terdapat dalam buku Bahasa Indonesia Kelas VIII. Buku teks kelas VIII dipilih karena pada kelas tersebut, karya sastra terutama puisi lebih banyak disampaikan dibandingkan kelas VII maupun kelas IX. Buku teks yang dimaksud adalah buku terbitan pemerintah melalui Kementrian 
Pendidikan dan Kebudayaan Republik Indonesia tahun 2017.

Data penelitian berupa informasi yang berupa kata, frasa, atau kalimat yang terdapat dalam puisi yang dapat mewakili identitas nasional dan identitas sosial sesuai tujuan penelitian yang telah ditetapkan. Puisi-puisi tersebut adalah Hujan Bulan Juni (Sapardi Djoko Damono), Gadis Pemintaminta (Toto Sudarto Bachtiar), Surat dari Ibu (Asrul Sani), Doa (Amir Hamzah), Serenada Hijau (WS Rendra), Senja di Pelabuhan Kecil (Chairil Anwar), Ode buat Proklamator (Leon Agusta), Peristiwa Pagi Tadi (Sapardi Djoko Damono), Tengadah ke Bintang-Bintang (Jujun Suriasumantri), Peninjauan Nuklir (Eka Budijanta), Sajak (Sanusi Pane), Doa (Charil Anwar), Tanah Kelahiran I (Ramadhan KH), Senjakala Gunung Merapi (Linus Suryadi), dan Tengadah ke Bintang-Bintang. Instrumen penelitian pada penelitian ini adalah peneliti sebagai pelaku riset seluruh tahapan penelitian mulai dari perencanaan, pengumpulan data, analisis, dan penarikan kesimpulan. Konsep identitas nasional yang diteliti dalam tulisan ini hanya berupa suku bangsa, agama, bahasa, dan budaya atau adat.

\section{HASIL DAN PEMBAHASAN Hasil}

Berdasarkan penelitian terhadap puisi yang terdapat dalam buku teks Bahasa Indonesia kelas VIII diperoleh hasil bahwa identitas nasional yang muncul adalah identitas suku bangsa, bahasa, agama, dan adat. Identitas suku bangsa muncul pada puisi Tanah Kelahiran I dan Senjakala Gunung Merapi. Sementara itu, identitas agama muncul dalam puisi Tengadah ke Bintang-Bintang dan Doa. Identitas nasional lainnya yang muncul adalah identitas adat istiadat atau budaya. Identitas budaya muncul dalam puisi Tanah Kelahiran. Identitas bahasa muncul di semua puisi karena puisi yang dimuat adalah puisi berbahasa Indonesia.

Identitas suku bangsa muncul salah satunya pada puisi Tanah Kelahiran. Pada puisi tersebut, identitas suku bangsa ditunjukkan dalam bentuk kata kebaya dan pewayangan.
Kata kebaya menunjukkan suku-suku bangsa di Jawa yang menggunakan kebaya sebagai pakaian adat, misalnya suku Betawi, Jawa, dan Bali. Selain kebaya, ditemukan pula kata pewayangan. Kata pewayangan yang digunakan menunjukkan suku Jawa dan Sunda yang salah satu kekayaan budayanya adalah pewayangan.

Identitas nasional selanjutnya yang ditemukan dalam puisi di buku teks Bahasa Indonesia Kelas VIII adalah identitas bahasa. Identitas bahasa dapat ditemukan melalui bahasa-bahasa yang digunakan dalam puisi yang terpilih. Puisi-puisi yang digunakan secara umum menggunakan bahasa Indonesia. Meksipun demikian, terdapat beberapa kata yang berasal dari bahasa daerah. Kata-kata tersebut di antaranya adalah kata ngungun, menyidem, kelengan dan tatit (Senjakala Gunung Merapi), goblog (Tengadah ke Bintang-bintang),

Identitas nasional lainnya yang muncul adalah identitas agama. Identitas agama muncul dalam puisi Tengadah ke Bintang-bintang dan Doa. Dalam puisi Tengadah ke Bintangbintang, identitas agama muncul melalui kata hamba dan Tuhan. Selain dalam puisi Tengadah ke Bintang-bintang, identitas agama juga muncul dalam puisi Doa. Kemunculan identitas tersebut melalui kata Tuhanku, nama$M u$, Kau, Caya-Mu, dan pintu-Mu.

Selain identitas nasional berupa bahasa, agama, suku, dan budaya, terdapat identitas nasional Indonesia yakni adanya burung garuda (Ode buat Proklamator). Burung Garuda merupakan lambang identitas negara Indonesia yakni sebagai lambang negara yang di dalamnya terdapat landasan filosofis bangsa Indonesia (yakni Pancasila) dan semboyan Bhinneka Tunggal Ika.

\section{Pembahasan}

Puisi sebagai salah satu karya sastra merupakan salah satu simbol jati diri bangsa Indonesia, karena pada dasarnya karya sastra tersebut merupakan ekspresi pengalaman dan penghayatan masyarakat terhadap kehidupan berbangsa dan bernegara. Dengan demikian, segala sesuatu yang tercermin dalam puisi 
yang ditulis pada dasarnya juga merupakan pengungkapan identitas dan jati diri bangsa Indonesia. Secara universal, puisi mengandung berbagai nilai positif yang bermanfaat bagi pembentukkan dan pembinaan karakter pembacanya, termasuk nilai positif dalam menggugah nilai dan rasa kebangsaan sebagai sebuah identitas.

Identitas bahasa merupakan identitas nasional yang sangat jelas kehadirannya dalam puisi-puisi tersebut karena keseluruhan puisi ditulis dengan menggunakan bahasa Indonesia. Penggunaan bahasa Indonesia dalam puisi memenuhi fungsi memperkuat identitas sebagai sebuah bangsa, yaitu bangsa Indonesia dan memperkuat rasa solidaritas antarwarga negara yang berasal dari berbagai suku bangsa beserta bahasa daerah masing-masing. Bahasa yang digunakan oleh seseorang merupakan manifestasi dari pikiran yang dimiliki oleh seseorang tersebut, termasuk ideologi-ideologi yang diyakini oleh seseorang. Bahasa juga dapat menjadi penanda identitas kelompok seseorang. Melalui ekspresi bahasa, seseorang dapat dimasukkan ke kelompok-kelompok yang dianggap memiliki kesamaan ekspresi bahasa (Edwards, 2009: 19). Bahasa Indonesia juga dalam karya sastra dianggap sebagai nation building, bahkan sejak angkatan Balai Pustaka. Karya sastra bukan hanya menjadi dinding identitas pengarangnya saja, akan tetapi pengarang tersebut juga menorehkan identitas sebuah bangsa.

Meskipun demikian, terdapat beberapa kosa kata bahasa daerah yang digunakan dalam puisi meskipun keberadaannya tidak dalam jumlah yang besar. Bahasa daerah yang digunakan dalam puisi di buku teks bahasa Indonesia kelas VIII di antaranya adalah bahasa Jawa, yakni kata "ngungun" pada puisi Senja Kala Gunung Merapi yang berasal dari bahasa Jawa. Penggunaan bahasa daerah dalam puisi justru menguatkan identitas nasional bangsa Indonesia yang terdiri atas berbagai suku bangsa dengan bahasa daerahnya masingmasing.

Penggunaan bahasa daerah dalam berbagai puisi merupakan bentuk penulis dalam mengekspresikan budayanya, di samping adanya keterbatasan penerjemahan sehingga dikhawatirkan kata tersebut akan hilang maknanya jika diekspresikan dalam bahasa Indonesia. Melalui berbagai bentuk kebahasaan, termasuk bentuk bahasa daerah, bahasa yang ada dalam puisi dapat memberikan sentuhan yang lain dari biasanya sehingga memberikan efek lain terhadap pembacanya (Nurgiyantoro, 2007:313).

Puisi Senja Kala Gunung Merapi ditulis oleh Linus Suryadi Ag yang dikenal konsisten menulis puisi prosaik dengan ungkapanungkapan bahasa Jawa yang khas. Selain itu, Linus juga dianggap berhasil mencakup ruang batin dan jasmani orang Jawa melalui lirik-lirik yang serba ringkas. Hal tersebut tidak terlepas dari pergulatan batinnya dalam menentukan identitas diri dan pertanyaan-pertanyaan tentang kehadirannya sendiri. Melalui puisi Senja Kala Gunung Merapi tersebut, pembaca dapat melihat identitas keindonesiaan salah satunya melalui kosa kata bahasa Jawa yang digunakan dan mempertegas kelindan antara ruang batin pembaca. Penggunaan bahasa Jawa tersebut juga memungkinkan timbulnya pertanyaan pada pembaca, dalam hal ini adalah siswa mengenai kosa kata berbahasa Jawa yang digunakan. Kosa kata berbahasa Jawa tersebut sekaligus dapat berfungsi sebagai agen penyebar identitas kebangsaan Indonesia, yakni adanya bahasa daerah yang beragam yang tidak mengurangi keindahan sebuah karya sastra. Hal tersebut sekaligus menguatkan identitas nasional bangsa Indonesia yang terdiri atas berbagai macam suku dan adat istiadat.

Identitas nasional lainnya yang muncul dalam puisi buku teks Bahasa Indonesia kelas VIII adalah agama. Puisi-puisi di atas tidak menunjukkan identitas agama tertentu yang ada di Indonesia, melainkan menampilkan gambaran universal Indonesia yang mempercayai Tuhan dan taat beragama. Hal tersebut menggambarkan kedudukan agama sebagai salah satu identitas yang dimiliki oleh bangsa Indonesia. Bahkan, secara khusus di Indonesia terdapat genre kesusastraan yang disebut dengan sastra keagamaan yang menurut Goenawan Mohammad dilatarbelakangi oleh dua faktor utama, yakni adanya motif pencarian 
identitas sastrawan penulisnya dan motif di luar sastra yakni adanya pengaruh rivalitas antargolongan dalam masyarakat (Wachid, 2017).

Identitas agama dapat muncul dalam bentuk kata, citraan, maupun metafora-metafora yang digunakan dalam puisi. Identitas agama di antaranya muncul pada puisi Doa karya Amir Hamzah. Puisi Doa lebih merupakan ungkapan perasaan seseorang terhadap kekasihnya. Hal tersebut dapat dilihat mulai bait pertama yakni "Dengan apakah kubandingkan pertemuan kita, kekasihku?". Meskipun tema yang diangkat adalah tema romantisme, Amir Hamzah mengemasnya dalam judul Doa. Penggunaan judul Doa tersebut menunjukkan identitas penulis yang mengakui keberadaan kekuatan yang melebihi apapun. Hal tersebut mengindikasikan masyarakat Indonesia yang percaya terhadap Tuhan dan agama.

Puisi lain yang menampilkan agama sebagai identitas nasional adalah puisi Tengadah ke Bintang-bintang. Dalam puisi tersebut terdapat frasa "O, Tuhan" yang menunjukkan pengakuan terhadap adanya Tuhan. Selain itu terdapat pula frasa "berilah hamba kearifan" dan "bimbinglah si goblok dalam menemukan sebuah ujud maknawi". Melalui pemilihan diksi tersebut, Jujun S. Surjasumantri menggambarkan kepasrahan kepada Tuhan yang diwujudkan dengan praktik doa. Berdoa merupakan salah satu ritual yang dimiliki oleh orang-orang yang beragama. Puisi Tengadah ke Bintang-bintang berisi doa seorang hamba agar dikaruniai petunjuk untuk bisa menyerap ilmu pengetahuan. Secara tidak langsung penulis menunjukkan bahwa manusia tidak memiliki kemampuan untuk memahami ilmu pengetahuan tanpa adanya bantuan dari Tuhannya.

Puisi dan doa memiliki keterkaitan, larik-larik doa yang terdapat dalam kitabkitab suci agama memiliki tingkat keindahan dan estetika. Meskipun tingkatan keindahan doa yang terdapat dalam karya sastra berbeda dengan keindahan doa yang ditemukan di kitab suci, doa-doa yang tertuang dalam karya sastra mampu menunjukkan kecintaan manusia terhadap Tuhannya. Puisi-puisi yang benafas religi sesuai dengan tema spiritual yang diusung oleh agama secara universal karena mengusung cinta kasih terhadap sesama dan merupakan salah satu perwujudan resiprokal cinta Tuhan terhadap manusia (Watson, 2007).

Adat istiadat juga menjadi bagian dari identitas nasional yang muncul dalam teks sastra, khususnya puisi yang dimuat dalam buku teks Bahasa Indonesia kelas VIII. Salah satu adat yang muncul adalah kebaya dan wayang. Kebaya merupakan busana nasional perempuan Indonesia ditetapkan pada masa Ibu Negara Tien Soeharto dengan didasarkan pada pertimbangan a) tidak mencerminkan kedaerahan, b) bisa dimiliki oleh setiap lapisan masyarakat, c) mudah didapat, mudah dirawat, dan harganya terjangkau, serta d) tidak lepas dari unsur etika dan estetika berbusana (Suciati, Suchari, \& Kahdar, 2015).

Busana kebaya merupakan salah satu adat yang merepresentasikan jatidiri perempuan Indonesia yang lebih mengedepankan nilai feminitas. Di samping model, bentuk, serta fungsinya yang mencerminkan nilai feminitas masyarakat Indonesia, kebaya juga merupakan penada yang merepresentasikan identitas kolektif dari tata nilai dan perilaku sosiokultural pemakainya (Suciati, Suchari, \& Kahdar, 2015). Kebaya sebagai salah satu gaya berbusana menjadi ekspresi identitas kebudayaan yang menjadi kekayaan kolektif masyarakat lokal. Busana tidak hanya dibatasi fungsinya sebagai pelindung tubuh, tetapi juga digunakan sebagai "public image" (Tomlinson, 2003). Penggunaan kata kebaya menunjukkan identitas nasional bangsa Indonesia yang masyarakatnya masih memegang nilai-nilai feminitas dalam kehidupan sehari-hari. Dalam puisi Tanah Kelahiran I, penulis menunjukkan kebyaa sebagai pakaian yang biasa dikenakan oleh wanita-wanita Indonesia. Hal tersebut juga selaras dengan judul puisi yakni Tanah Kelahiran yang jika dirangkai dengan badan puisinya menimbulkan pemahaman bahwa tanah kelahiran tersebut memiliki asosiasi dengan kebaya dan wayang sehingga secara tidak langsung memunculkan identitas nasional.

Selain kebaya, identitas adat yang terdapat dalam buku teks adalah wayang. Cerita 
dalam pewayangan saratakan budipekerti luhur, saling mencintai, dan menghormati. Selain itu, dalam pertunjukannya, wayang sering disisipi kritik sosial. Wayang kulit merupakan salah satu dari warisan budaya nusantara yang lahir dari masyarakat Indonesia asli dan memiliki makna filosofis yang kental. Oleh karenanya, wajar jika wayang menjadi salah satu ikon identitas budaya nasional. Kebaya dan wayang sebagai salah satu representasi adat serta bahasa daerah yang ada tidak dapat dipisahkan dari adanya identitas etnis yang menjadi kerangka identitas nasional. Pembentukan identitas nasional tidak dapat dipisahkan dari adanya identitas etnobudaya karena Indonesia merupakan negara yang terdiri atas berbagai suku bangsa dengan beragam kekayaan budayanya.

Penelitian ini melengkapi hasil kajian penelitian-penelitian sebelumnya yang membahas mengenai identitas keindonesiaan novel karya anak Indonesia (Suyatno, 2014), identitas kebangsaan yang ada pada puisi (Darmawati, 2017) dan identitas nasional dalam buku teks pelajaran sejarah SMA (Sumaludin, 2018) dengan menghadirkan perspektif baru, yakni identitas nasional dalam karya sastra, khususnya puisi, yang terdapat pada buku teks Bahasa Indonesia kelas VIII. Identitas nasional yang muncul dalam puisi buku teks bahasa Indonesia kelas VIII adalah identitas agama, budaya, bahasa, dan adat. Identitas nasional yang muncul dalam puisi-puisi buku teks Bahasa Indonesia kelas VIII memiliki porsi yang cukup kecil dibandingkan dengan keseluruhan puisi. Hal tersebut salah satunya berkaitan dengan tema yang digunakan dalam puisi-puisi tersebut. Darihasil penelitian dan dan analisis yang dilakukan juga ditemukan adanya identitas sosial yang kuat dalam puisi-puisi yang terdapat pada buku teks Bahasa Indonesia kelas VIII tersebut sehingga diperlukan kajian yang mendalam untuk mengungkap identitas sosial di balik puisi-puisi yang dijadikan bahan dalam pembelajaran sastra, khususnya di kelas VIII.

\section{SIMPULAN}

Pembelajaran sastra di sekolahsekolah bertujuan mengembangkan kepekaan siswa terhadap berbagai nilai yang terkandung di dalamnya, termasuk penanaman identitas nasional yang tergambar melalui puisi. Lebih dari itu, pembelajaran sastra, salah satunya melalui puisi, merupakan wadah untuk mengembangkan karakter, terutama karakter kebangsaan sebagai bekal menghadapi era disrupsi saat ini. Identitas-identitas nasional yang terdapat dalam karya sastra tersebut diharapkan secara tidak langsung mampu menumbuhkan kesadaran mengenai identitas nasional pada peserta didik. Karya sastra juga dianggap sebagai cara yang cukup efektif dalam meningkatkan pendidikan dan karakter kebangsaan, termasuk penanaman identitas kepada siswa melalui proses apresiasi karya sastra yang menjadi bagian pembelajaran bahasa Indonesia. Skema tersebut dapat berjalan jika peserta didik didukung dengan kesadaran berbahasa kritis dan kemampuan berpikir kritis sehingga identitas nasional yang muncul pada karya sastra tidak hanya terhenti sebagai sebuah produk, melainkan sebagai agen penanaman identitas nasional pada pembacanya.

\section{DAFTAR PUSTAKA}

Barker, C. (2004). The SAGE Dictionary of Cultural Studies. London: SAGE Publication Inc.

Barrett, M., \& Davis, S. C. (2008). Applying social identity and selfcategorization theories to children's racial, ethnic, national and state identifications and attitudes. In S. M. Quintana \&C. McKown (Eds.), Handbook of race, racism and the developing child (pp. 72-110). Hoboken: Wiley.

BPS. (2011). Kewarganegaraan, Suku Bangsa, Agama, dan Bahasa Sehari-Hari Penduduk Indonesia: Hasil Sensus Penduduk 2010. Jakarta: Badan Pusat Statistik.

Darmawati, B. (2017). Menggugah Identitas Kebangsaan Melalui Puisi. Jentera 6(1), Juni 2017

Edensor, T. (2002). National Identity, Popular Culture and Everyday Life. Oxford: Berg. 
Edwards, J. (2009). Language and Identity. Cambridge: Cambridge University Press.

Herdiawanto dan Juwanta. 2010. Cerdas, Kritis, dan Aktif Berwarganegara: Pendidikan Kewarganegaraan untuk Perguruan Tinggi. Jakarta: Erlangga.

Nurgiyantoro, B. (2007). Teori Pengkajian Sastra. Yogyakarta: Gadjah Mada University Press.

Suciati, Sachari, A., \& Kahdar, K. 2015. Nilai Feminitas Indonesia dalam Desain Busana Kebaya Ibu Negara. Ritme (1) 1, 52-59.

Sumaludin, M.M. 2018. Identitas Nasional dalam Buku Teks Pelajaran Sejarah SMA. Historial, 1(2), 97-104.
Suyatno. (2014). Identitas Keindonesiaan dalam Novel Karya Anak Indonesia. Litera, 13 (2), 293-301.

Tomlinson, J. (2003). Globalization and Cultural Identity. In D. Held (Ed.), The Global Transformations Reader: An Introduction to the Globalization Debate (pp. 269-277). Cambridge, UK: Polity.

Watson, G. (2007). Poetry and Prayer Beyond Words. The Way 46, (I) hal. 39-52).

Wachid, A. (n.d.). Dinamika Puisi Keagamaan di Indonesia. http://pbi.ums.ac.id/ wp-content/uploads/sites/15/2019/03/ Abdul-Wachid-BS_Dinamika-PuisiKeagamaan-di-Indonesia.doc 